\title{
Learning Languages in Study Abroad And at Home Contexts: A Critical Review of Comparative Studies
}

\author{
Sonia LóPEz SERRANO \\ Departamento de Filología Inglesa, Facultad de Letras \\ Universidad de Murcia
}

Received: 2 June 2009 / Accepted: 23 September 2009

ISSN: 1697-7467

\begin{abstract}
In the last two decades numerous studies have been conducted to document the language learning gains in a second language (L2) thought to be prompted by study abroad (SA) programs. Although different research syntheses have been attempted to take stock of the findings involved, no review to date has been conducted with a view to analyze those studies in which researchers have compared the learning effects of SA contexts and those of at home $(\mathrm{AH})$ regular classrooms. The present review is an attempt to identify the studies that have adopted this comparative approach and to critically assess the dimensions investigated, the methodology used and the main findings reported. A number of methodological issues awaiting to be addressed in future research are also discussed.
\end{abstract}

Key words: learning contexts, study abroad, second / foreign language acquisition.

Efectos de las estancias en el extranjero frente a la instrucción en el país de origen en la adquisición de lenguas: una revisión crítica de estudios comparativos.

RESUMEN: En las últimas dos décadas se han llevado a cabo numerosos estudios cuyo objetivo es documentar los beneficios lingüísticos que reportan las estancias en el extranjero (SA) en la adquisición de una segunda lengua (L2). Aunque algunas revisiones han intentado hacer balance de la investigación en el área, no se ha llevado a cabo ninguna revisión con la idea de analizar aquellos estudios en los que se han comparado los efectos de las estancias en el extranjero con la instrucción formal en el país de origen. La presente revisión tiene como fin identificar los estudios que han adoptado un enfoque comparativo, así como evaluar de forma crítica las dimensiones analizadas, la metodología empleada y los principales resultados reportados. También se discuten algunos aspectos metodológicos que deberían considerarse al llevar a cabo futuras investigaciones en el área.

Palabras clave: contextos de aprendizaje, estancias en el extranjero, adquisición de segundas lenguas / lenguas extranjeras.

\section{INTRODUCTION}

A widely held assumption expressed by both learners and parents, teachers and institutions is that those students who experience periods of study abroad come back home having improved their language skills dramatically. Indeed, these study experiences are thought to be one of the 
most effective means of becoming proficient in a second language (L2), particularly benefiting dimensions such as fluency, pronunciation, discursive abilities, or vocabulary. Furthermore, periods abroad are also considered to foster students' motivation to learn the L2, modify their approaches to language learning, and positively influence learners' lives in diverse ways by challenging their cultural perceptions and beliefs and broadening their minds.

As Freed (1998: 31) points out, these beliefs are reflected in the numerous university sponsored language study abroad programs being implemented worldwide. Indeed, this experience abroad has been considered so crucial in the acquisition of an L2, that countries such as Britain established a compulsory residence abroad requirement for language degree students 30 years ago. In other countries, such as the United States, even though most colleges and universities do not require students to participate in study abroad programs, they are strongly encouraged to take part in these learning experiences, particularly for language majors (Lafford, 2006: 26).

As a consequence of the increasing importance attributed to study abroad (SA) experiences, a growing body of research assessing the impact of these stays on learning began to emerge several decades ago. The general aim of research in the field is to ascertain whether the purported benefits of the study abroad (SA) experience can be supported by empirical evidence and, at the same time, investigate whether this combination of formal instruction and immersion in the target language results in greater gains than regular classroom learning. Furthermore, those studies that explore different learning contexts allow for comparison in terms of which contextual factors seem to be more conducive to learning and which dimensions and levels of language are more likely to develop in which context.

Two main strands of research can be distinguished according to their focus. The first one explores both learners' internal and external factors related to their experience abroad and how these factors may impact upon their learning. The second strand mainly focuses on the effects of the learning context on the development of linguistic skills. Using mostly ethnographic approaches, the first group of studies explores issues such as students' perceptions of the study abroad experience (Mendelson, 1998; Pellegrino, 1998; Polanyi, 1995; Wilkinson, 1998), intercultural understanding (Alred \& Byram, 2002; Williams, 2005), motivation (Isabelli-García, 2006), attitudes and beliefs (Tanaka \& Ellis, 2003; Yager, 1998), interaction and socialization (Cook, 2006; Dufon, 2006) and the manner in which these social, contextual, and interpersonal factors may impact upon students' language learning as a whole (Teichler \& Maiworm, 1997), or with respect to particular domains such as the acquisition of sociolinguistic or pragmatic competence (Barron, 2006; Marriot, 1995; Regan, 1995; 1998).

The second strand of research comprises studies that explore the development of several dimensions of the L2 in relation to each learning context, particularly the study abroad context. Though this group of studies began during the 1970s, it was not until the late 1980s that empirical research was more controlled and methodologically rigorous. Many studies published during the 1990s were aimed at predicting and measuring general language gains (Brecht, Davidson, \& Ginsberg, 1993; 1995) and assessing overall proficiency (Lapkin, Hart, \& Swain, 1995; Rivers, 1998). In contrast, other researchers have also been interested in exploring the acquisition of certain grammatical and/or lexical features, such as vocabulary development (Ife, Vives, Boix \& Meara, 2000; Milton \& Meara, 1995), grammatical abilities (Dekeyser, 
1990; 1991; Guntermann, 1992a; 1992b) or even discrete features such as Spanish copula choice (Lafford \& Ryan, 1992) or the use of the subjunctive (Isabelli \& Nishida, 2005). Oral abilities have also received a great deal of attention, with studies focusing on oral proficiency (Juan-Garau \& Perez-Vidal, 2007), oral fluency (Freed, 1995; Freed, Segalowitz \& Dewey, 2004; Segalowitz \& Freed, 2004), the use of communication skills (Isabelli-García, 2003; Lafford, 1995; 2004), and the development of phonological abilities, both productive and receptive (Diaz-Campos, 2004; 2006; Mora, 2005; 2006). Regarding the remaining skills, a few studies have focused on the assessment of multiple skills (Meara, 1994; Willis et al, 1977) and only two articles have investigated the development of listening comprehension (Ginsberg, 1992; Ginsberg, Robin \& Wheeling, 1992). Finally, in terms of literacy skills, scarce attention has been paid either to reading (Dewey, 2004; Kline, 1998) or writing (Freed, So \& Lazar, 2003; Sasaki, 2004, 2007, 2009).

As this body of research offers a complex picture of the effects of contexts of learning and, above all, of the benefits associated with the experience of studying abroad, the need for research syntheses to be developed has increased over the years. Thus, scholars such as Freed (1998) and Lafford (2006) have compiled and revised the work done in the field with different purposes in mind. Specifically, whereas Freed (1998) provided a comprehensive summary of the «state of the art» ten years ago, covering a wide range of studies and topics, Lafford's (2006) synthesis of research mainly dealt with studies which explored the acquisition of Spanish as a second language in different learning contexts. However, to the best of my knowledge, no review to date has paid attention to one of the main limitations detected in the design of many of the studies reported above, namely the lack of a control group of learners who remained in their home country while a comparative group of students was staying abroad (Rees \& Klapper, 2008: 97). If the benefits associated with the latter context are not compared to those achieved in the regular classroom, students' gains cannot safely be assumed to be the outcome of the SA experience. There is thus a pressing need for the body of research which compares the effects of these two learning contexts - study abroad (SA) and the regular classroom at the home country $(\mathrm{AH})$ - to be identified and critically analyzed. This is the purpose of the present paper.

\section{Aims And SCOPe of the ReView}

The present review was intended to cover the strand of research within SA studies in which researchers have compared language learning in SA and AH contexts. With this purpose in mind, and as is common practice in systematic research syntheses (Norris \& Ortega, 2006), I was guided by the following research questions:

1. Which linguistic dimensions have been the focus of SA and AH comparative studies?

2. What methodological procedures have been used in this body of research?

3. Which learning context seems be more conducive to the development of particular dimensions of language learning? 


\section{Methodology OF THE REVIEW PROCESS}

\subsection{The search process}

Data for this synthesis were collected mainly through a process of searching the online ERIC database which involved introducing the search terms «study abroad» OR «stay abroad» as keywords and then refining the search by adding the terms "at home», «target culture», «effect(s)», «comparison», «(different)learning context(s)» OR «context of learning», «gains», «second language», «foreign language», «acquisition» and «skills» both combined and individually. Finally, the terms «pragmatic», «grammar», «pronunciation» and «sociolinguistic» were independently combined with «study abroad» OR «context» AND «effect». There was no need to specify a date range because the majority of studies were conducted from the $1980 \mathrm{~s}$. In addition, the online journal database provided by the University of Murcia, GALILEUM, was also used. After introducing the keywords «study abroad» AND «language», ScienceDirect and Blackwell Synergy were identified as the databases which included more relevant articles related to this issue. Thus, both databases were searched employing similar terms to those specified above. I also searched the reference list found in the book Language Learners in Study Abroad Contexts (Dufon \& Churchill, 2006). Since the journal Frontiers provided a large number of articles dealing with study abroad experiences, I scanned its table of contents. Other journals which contained a large number of references were also noted and consulted (when available) at the University of Murcia electronic resources. The journal Foreign Language Annals and a monograph volume on contexts of learning of the journal Studies in Second Language Acquisition were also identified as relevant sources. Finally, I also scanned the bibliographies of the above mentioned literature reviews (Freed 1998; Lafford 2006) and the references included in most recent articles on the topic.

The abstracts of all the papers retrieved were scanned so as to select only those which truly focused on the comparison of learning contexts (those studies in which researchers compared study abroad and stay at home learning experiences) and, in addition, complied with the following set of criteria:

1. I selected empirical studies published in English which compared the effects of the study abroad context with those of formal instruction «at home» on diverse dimensions of language acquisition.

2. In order to make the revision task manageable, the search was restricted to published research (books, book chapters and journal articles).

3. Papers originating from conferences with free Internet access were also included.

4. Those studies which compare the study abroad context with domestic immersion programs were excluded from the analysis.

5. Studies which explore learning context effects following the progress of only one group of students throughout various periods and contexts were also excluded.

Through the above mentioned combined search procedures, a set of 16 articles was obtained and this was taken to constitute the data of the present review. 


\subsection{The review approach}

The analysis of the studies included in this review followed a number of parameters (which were expressed in tabular form) within 3 general macro-categories: (a) areas studied; (b) methodological issues; and (c) research findings. These three macro-categories guided the analysis of the research undertaken in the next section.

\section{RESULts}

\subsection{Areas studied}

Several areas of interest can be identified in the studies reviewed, although attention has mostly been paid to oral skills and oral performance as shown by the number of studies focused on these issues. Two studies have explored the effects of stays abroad on pronunciation, focusing on the acquisition of certain types of Spanish sounds (Díaz-Campos 2004) and exploring the effects of style (formal vs. informal) on pronunciation (Díaz-Campos, 2006). Three further studies (DeKeyser 1991; Lafford 1995, 2004) investigated the use of oral communication strategies as a result of differences in context of learning. Finally, oral fluency (Freed, 1995) and oral performance (Freed, Segalowitz, \& Dewey 2004; Segalowitz \& Freed 2004) have also been the focus of three studies.

With regard to the other three skills, writing has been approached from the perspective of the effects of contextual factors on writing fluency (Freed, So \& Lazar, 2003) or on writing development, processes, strategies, and motivation (Sasaki 2004, 2007, 2009). In addition, Huebner's (1995) study explored the effects of stays abroad in absolute beginners, investigating several areas such as listening and reading comprehension, oral and pragmatic abilities, and language learning strategies.

Finally, another set of studies has investigated the development of general grammatical and lexical abilities (Collentine, 2004), the monitoring of grammatical knowledge (DeKeyser, $1990,1991)$ and the use of morpho-syntactic and semantic patterns such as the use of the subjunctive (Isabelli \& Nishida, 2005).

\subsection{Methodological issues}

\subsubsection{Participants}

\section{Number}

As can be seen in the Appendix, the number of participants varies widely across studies. However, the general trend is for sample sizes to be kept relatively small, ranging from 8 students (Freed, So and Lazar, 2003) to 61 learners (Isabelli \& Nishida 2005). In general terms, small scale studies have adopted a more qualitative approach, using several data sources such as interviews, diaries and observation (DeKeyser 1990, 1991; Sasaki 2004, 2007, 2009). In contrast, those studies which include a larger number of students mainly use quantitative pre- and post-tests. Surprisingly enough, only two studies include the same number of participants in each group $(\mathrm{AH}=15 ; \mathrm{SA}=15)$ (Freed 1995; Freed, So and Lazar 2003). 


\section{$L 1$ and $L 2$}

An aspect worth mentioning is the conspicuous lack of diversity regarding the students' mother tongue (L1) and their second language (L2). English is the participants' L1 in 13 out of the 16 studies reviewed, Sasaki's $(2004,2007,2009)$ students being the only ones with a different linguistic background (native speakers of Japanese). With regard to the L2, nine studies have focused on students of Spanish as a second language (see the appendix), three have investigated the effects of context on the development of English (Sasaki, 2004, 2007, 2009), and another three have looked at the acquisition of French (Freed, 1995; Freed, So \& Lazar, 2003; Freed, Segalowitz, \& Dewey, 2004), while only one has investigated learners of Japanese (Huebner, 1995).

\section{Proficiency level}

Participants were all university students and, although some kind of information is always provided about their L2 proficiency, this information is not very precise in all cases. Only six studies report the participants' levels of proficiency (DeKeyser, 1990; 1991; Díaz Campos, 2004; Huebner, 1995; Isabelli \& Nishida, 2005; Sasaki 2007), while the rest of studies either provide only information about the number of years of students' L2 previous instruction (Sasaki 2004, 2009) or equate the semester they are placed in with a specific proficiency level. In this latter case, however, three authors (Freed 1995; Freed, So \& Lazar 2003; Lafford 1995) acknowledge that, even though their participants attended the same semester in their language courses, there was great diversity in terms of proficiency within groups. For comparison purposes, SA and AH students are usually reported to be similar in terms of proficiency, the exception being only one study (Isabelli \& Nishida, 2005) that compares groups of different proficiency levels $(\mathrm{AH}=$ intermediate; $\mathrm{SA}=$ advanced $)$.

\subsubsection{Research designs and instruments}

\section{Duration}

Concerning the length of the period studied, and as can be seen in the Appendix, most studies ( 7 out of 12) limit the exploration of the study abroad experiences to one semester (16 weeks) or even to shorter periods such as summer courses abroad (nine weeks in the case of Huebner, 1995). Only in one study has the time span been broadened to one academic year (Isabelli \& Nishida, 2005), while in the series of studies carried out by Sasaki (2004, 2007, 2009) the duration period of stays abroad ranges from 2 to 11 months.

\section{Design}

Regarding the design of the studies, only one author (Lafford 1995) adopted a crosssectional approach so as to investigate students' linguistic gains after a period abroad. In the rest of studies (all of them longitudinal in nature), two main trends can be identified. On the one hand, nine studies (see the appendix) focus on the outcomes of the residence abroad period, using pre- and post- treatment standardized proficiency tests for the measurement of linguistic progress and restricting their assessment to the analysis of the quantitative data collected. On the other hand, six studies pay attention not only to linguistic gains at the end of the SA period, but also to the gradual development of the linguistic dimensions analyzed. In general terms, this set of studies collects samples of students' performance at least three 
times during the observation period and combine both quantitative and qualitative approaches so as to gain further insight into the students' linguistic development. Finally, the only studies which investigate long terms effects of stays abroad are those conducted by Sasaki (2004, 2007, 2009).

\section{Instruments}

Concerning the instruments employed to assess learners' linguistic development, most studies (11 out of 16) rely mainly on the Oral Proficiency Interview (OPI). This test is used to measure not only oral abilities and pronunciation, but also the use of some morpho-syntactic patterns such as the Spanish subjunctive (Isabelli \& Nishida, 2005) or the development of vocabulary (Collentine, 2004). Only one author (DeKeyser, 1990, 1991) uses tasks (a grammar test and a picture description task) specifically oriented towards the assessment of grammatical performance and monitoring. In addition, those studies that combine quantitative and qualitative data sources have used interviews to gather further information about the students' attitudes, motivation (Sasaki 2004, 2007, 2009), self-reported learning behaviors (DeKeyser, 1990, 1991), and learning experiences (Huebner 1995; Segalowitz \& Freed 2004). In some cases, the observation of participants in and out of class (DeKeyser, 1990, 1991; Huebner 1995) and the completion of learning journals by the students (Huebner 1995; Segalowitz \& Freed 2004) have also been used as additional data sources.

\subsection{Research findings}

As mentioned above, within the set of comparison studies, only one author (Huebner 1995) has explored students' gains in several linguistic dimensions. The rest of studies have focused on participants' specific development in one of these three main areas: lexical and grammatical acquisition and performance, oral abilities (including pronunciation, oral fluency and performance and oral communication strategies), and writing skills.

\subsubsection{Linguistic progress in several areas}

No statistically significant differences were found in any of the areas investigated by Huebner (1995: 183), although several trends could be identified. Students in both groups did not seem to differ in their listening comprehension, pragmatic abilities or in their use of learning strategies, but the SA students showed a slight advantage in reading comprehension. These students also demonstrated more positive attitudes towards language learning: while the $\mathrm{AH}$ group resisted the introduction of Katakana and Hiragana alphabets early in the course, the SA group enthusiastically welcomed the inclusion of these aspects of the Japanese writing system (p. 185).

\subsubsection{Lexical and grammatical development}

Those studies dealing with grammatical and lexical development have explored the acquisition of both general morpho-syntactic patterns (Collentine, 2004) as well as specific aspects such as the use of the Spanish subjunctive (Isabelli \& Nishida, 2005), the ability to monitor grammar (DeKeyser, 1990, 1991), the development of narrative abilities and vocabulary acquisition (Collentine, 2004). 
Findings concerning grammatical accuracy are somewhat mixed. Isabelli and Nishida (2005) found that the SA group outperformed the AH group in the use of the Spanish subjunctive. Whereas no clear evolution was found in the AH groups, the SA group made great progress from the beginning to the middle of the academic year and then continued improving, though only slightly (p. 89). In contrast, Collentine (2004) reported that the SA experience did not help students improve their grammatical abilities, and that the AH group even outperformed SA learners in those aspects usually emphasized in Spanish formal instruction (p. 240). In terms of monitoring abilities, the two studies conducted by DeKeyser $(1990,1991)$ confirm the lack of superiority of the SA context regarding grammatical abilities. Dekeyser found that the AH group was equal or even superior to the SA group in the ability to monitor and accurately use grammatical forms in both studies.

Findings in grammatical development are further supported by those in vocabulary acquisition. Collentine (2004) found that the stay abroad does not promote higher acquisition or the production of more semantically dense words. Quite the contrary, the only significant difference between the two groups was found in adjectives, with the AH producing proportionally more unique adjectives after the observation period than the SA group (p. 242). In contrast, the two authors who paid attention to narrative abilities (Collentine 2004; DeKeyser 1990) reported that the SA group seemed to outperform the AH group in this area.

\subsubsection{Oral abilities}

As suggested above, students' development of oral abilities is the area most widely investigated, including studies on pronunciation, oral communication strategies, and oral fluency, proficiency, and performance.

Concerning the oral production of native-like variants, findings reported by Díaz Campos (2004, 2006) suggest that SA students tended to produce more target like variants than AH students in informal, conversational tasks (Díaz Campos, 2006: 37). In contrast, no significant differences between groups were found in reading aloud (formal) tasks. In terms of the number and range of communication strategies (CSs) used by learners, the findings reported are highly diverse. Whereas DeKeyser (1991) found no statistically significant differences in the number and types of CSs used by the two groups, Lafford (1995) found that SA learners possessed a wider range of discourse management strategies (e.g., ways of opening and closing a conversation) than the AH group. However, in a later study, Lafford (2004) reported that the SA group used significantly fewer CSs than the AH in the post-test, which might be taken as an indication that SA students were able to maintain a conversation without resorting continually to CSs (p. 217).

Findings are more consistent regarding students' development of oral fluency, since many studies, even those which did not focus particularly on this dimension, report that SA students appear to be more fluent than their AH counterparts (Collentine 2004; DeKeyser 1991; Freed 1995; Freed, Segalowitz \& Dewey 2004; Huebner 1995; Segalowitz \& Freed 2004). In Freed (1995) both native speaker judges and analytic measures yielded similar results: students who had spent a semester abroad spoke more and at a significantly faster rate» (p. 141). In addition, their speech tended to reveal fewer clusters of dysfluencies and longer streams of continuous speech. Segalowitz and Freed (2004) claim that, in their study, SA students were the only ones who made gains in fluency, as the AH group did not show any significant 
progress. In fact, this lack of development in the AH group in terms of fluency is confirmed by Freed, Segalowitz \& Dewey's (2004). Furthermore, according to Segalowitz and Freed (2004: 184) students' oral proficiency as measured by the OPI also seems to benefit from residence abroad, since they found that only SA students made significant gains in this measure. Though not statistically significant, an advantage for the SA group in terms of proficiency was also reported by Huebner (1995: 184).

\subsubsection{Writing}

Only four studies have explored the effects of stays abroad on writing skills, not only within the body of comparison studies, but within research on contexts of learning in general. While the study conducted by Freed, So and Lazar (2003) mainly dealt with the development of written fluency, the other three studies, which have been conducted by the same author (Sasaki, 2004, 2007, 2009), have broadened their focus to students' writing fluency, writing ability, strategy use, writing styles, and students' attitudes towards writing, confidence and motivation.

Writing fluency has been explored in three of these studies and their findings are varied. Two studies (Freed, So \& Lazar 2003; Sasaki 2004) reported no significant differences between groups in total number of words written, and Freed, So and Lazar (2003: 37) even pointed out that native speaker judges perceived the writing fluency of the AH students to be higher than that of the SA students in both pre- and post-tests. On the contrary, Sasaki (2007) found that SA learners improved in both speed of writing and quantity of words written, while $\mathrm{AH}$ students' fluency decreased (p. 608).

In terms of writing ability as measured by composition scores, only one of the three studies conducted by Sasaki (2004: 546) reported no significant differences between groups. In contrast, the other two studies by the same author (Sasaki, 2007, 2009) indicated that whereas the SA group's mean tended to improve, AH students' scores decreased. Particularly, Sasaki (2009) explains that AH students' scores went on decreasing during the last years of their degree, some of them even dropping below their initial level. In contrast, those students who had spent more than eight months abroad kept improving until their senior year.

Regarding students' development of writing styles, Sasaki (2004) found no differences between groups. However, in a later study (Sasaki, 2007), she reported that writing styles tended to be developed more by the SA group. When the results of both studies are compared in terms of the variables which influence writing styles, it seems that writing instruction plays a more important role than context of learning: whereas all the participants in Sasaki's (2004) study had received explicit writing instruction, which supposedly conditioned their writing styles, the students in the second study (Sasaki, 2007) had not. In this case, only the students who had stayed abroad were able to change their approach to writing.

In terms of on students' use of L2 writing strategies, the two studies conducted by Sasaki (2004, 2007) yield mixed results. As it was the case with styles, both groups of students use of strategies, particularly regarding translation from the L1 and use of local planning, seem to vary according to the writing instruction and practice enjoyed in each learning context.

A final dimension which has been investigated is the students' attitudes towards writing and their own writing progress, particularly in terms of confidence and motivation. In general terms, Sasaki's studies $(2004,2007,2009)$ reveal two main variables that affect students' 
attitudes: amount and type of writing instruction, and context of learning. In fact, both groups of students (AH and SA) tended to feel more confident when writing in their L2 if they had received writing instruction at the beginning of their degree studies. When no previous writing instruction had been received, only those students who went abroad became more motivated to write better compositions and felt more confident when writing in English. Indeed, AH students, who had not received explicit writing instruction, did nothing to improve their writing throughout the observation period and all of them felt that writing had become more difficult and that their English proficiency had worsened at the end of their degree studies (Sasaki, 2007). In contrast, most SA students claimed that their experience abroad had motivated them to write better texts (Sasaki 2007, 2009), and those who had spent more than four months abroad seemed to have formed «L2-related imagined communities» that motivated them to voluntarily practice writing.

\section{Concluding remarks}

This review was intended to provide a synthesis of the body of empirical research exploring the effects of stays abroad on L2 acquisition by means of comparing the SA context with a control group at home. In terms of the results found in the linguistic dimensions investigated, overall, it seems that the SA context favors the development of oral skills, since the studies analyzed report that students' oral performance seem to benefit from study abroad experiences, allowing them to outperform those students who remain at home attending regular classes. Furthermore, SA students tend to produce more native-like phonological variants during informal conversation and they need to resort less to oral communication strategies. In contrast, grammatical abilities such as monitoring the accuracy of linguistic productions, the acquisition of discrete grammar points or the development of vocabulary do not seem to be better acquired in a study abroad context. Finally, the findings regarding writing are quite complex since studies report conflicting results concerning aspects such as written fluency or writing styles. However, in general terms, stays abroad seem to be conducive to students' improvement of their writing abilities and, above all, they appear to foster students' confidence and motivation while writing.

In spite of the findings reported above, several issues still need to be examined in future research. In terms of methodological concerns, two important limitations of the studies reviewed relate to participants and study design. Concerning the participants included in this body of research, group sizes are extremely small in sampling terms and in the majority of studies the number of participants included in each group differs greatly. It would be interesting to address these issues in future research so as to allow for generalizations and more valid comparisons. Furthermore, considering the rather limited range of languages investigated to date, it seems crucial that future research attempts to further analyze the acquisition of the languages explored so far and expand the variety of mother tongues and second languages explored so as to account for students' diversity in terms of both linguistic backgrounds and L2s. In addition, students' educational background should be more homogeneous to allow for reliable comparisons. It is crucial to ensure that students are truly comparable so as to answer the key question of «what progress would the study abroad group have made if it had stayed home?» (Rees \& Klapper, 2008: 97). 
Regarding the design of the studies, most authors have focused on semesters abroad, mainly because they are restricted by national educational differences concerning the desired length of residence abroad. Nevertheless, future research should try to explore the benefits of longer periods of study abroad and, above all, there is a pressing need for exploring long-term effects of stays abroad, since no study, apart from those conducted by Sasaki (2004, 2007, 2009), has investigated long-term retention of SA gains. In terms of data collection methods, most studies have relied on the oral proficiency interview to assess students' development in different dimensions. However, this instrument should be substituted for or at least complemented with other types of measures designed to capture progress in different areas. Furthermore, future studies should try to collect their data at several points in time, combining both quantitative and qualitative approaches when possible in order to explore not only learning outcomes, but also the learning processes that take place in the study abroad context. In fact, learning processes have almost been neglected in study abroad studies.

These are only a few of many issues awaiting to be addressed in future research endeavors. As such, they show that, even though the number of studies related to study abroad experiences has increased considerably during the last decade, this area of research, as DuFon and Churchill (2006: 26) suggest, «is still in its infancy».

\section{ACKNowledgements}

I would like to thank my advisors, Dr. R. Manchón and Dr. J. Roca de Larios, for their support and their insightful comments on earlier versions of this manuscript.

\section{REFERENCES}

Alred, G. \& Byram, M. (2002). «Becoming an intercultural mediator: A longitudinal study of residence abroad». Journal of Multilingual and Multicultural Development, 23(5): 339-352.

Barron, A. (2006). «Learning to Say 'You' in German: The Acquisition of Sociolinguistic Competence in a Study Abroad Context». In M. A. DuFon \& E. Churchill (eds.), Language Learners in Study Abroad Contexts. (pp. 59-90). Clevedon: Multilingual Matters.

Brecht, R., Davidson, D. \& Ginsberg, R. (1993). Predictors of Foreign Language Gain during Study Abroad. Washington D.C.: National Foreign Language Center.

Brecht, R., Davidson, D. \& Ginsberg, R. (1995). «Predicting and measuring language gains in study abroad settings». In B.F. Freed (ed.), Second Language Acquisition in a Study Abroad Context (pp. 37-66). Amsterdam: John Benjamins

Churchill, E. \& DuFon, M. A. (2006). «Evolving Threads in Study Abroad Research». In M. A. DuFon \& E. Churchill (eds.) Language Learners in Study Abroad Contexts. (pp. 1-27). Clevedon: Multilingual Matters.

Collentine, J. (2004). "The Effects of Learning Contexts on Morphosyntactic and Lexical Development». Studies in Second Language Acquisition, 26(2): 227-248.

Cook, H. M. (2006). «Joint construction of folk beliefs by JFL learners and Japanese host families». In M. A. DuFon \& E. Churchill (eds.), Language Learners in Study Abroad Contexts. (pp. 120-150). Clevedon: Multilingual Matters. 
DeKeyser, R. (1990). «From learning to acquisition? Monitoring in the classroom and abroad». Hispania, 73: 238-247.

Dewey, D. P. (2004). «A Comparison of Reading Development by Learners of Japanese in Intense Domestic Immersion and Study Abroad Contexts». Studies in Second Language Acquisition, 26(2): 303-327.

Díaz-Campos, M. (2004). «Context of Learning in the Acquisition of Spanish Second Language Phonology». Studies in Second Language Acquisition, 26(2): 249-273.

Díaz-Campos, M. (2006). «The Effect of Style in Second Language Phonology: An Analysis of Segmental Acquisition in Study Abroad and Regular-Classroom Students». In C. A. Klee $\&$ T. L. Face (eds.) Selected Proceedings of the 7th Conference on the Acquisition of Spanish and Portuguese as First and Second Languages (pp. 26-39). Somerville, MA: Cascadilla Press.

DuFon, M. A. (2006). «The socialization of taste during study abroad in Indonesia». In M. A. DuFon \& E. Churchill (eds.), Language Learners in Study Abroad Contexts. (pp. 91-119). Clevedon: Multilingual Matters.

Freed, B. F. (1995). «What makes us think that students who study abroad become fluent?» In B. Freed (ed.), Second Language Acquisition in a Study Abroad Context (pp. 123-148). Amsterdam: John Benjamins.

Freed, B. F. (1998). «An Overview of Issues and Research in Language Learning in a Study Abroad Setting». Frontiers. 4: 31-60.

Freed, B. F., Segalowitz, N. \& Dewey, D. P. (2004). «Context of Learning and Second language Fluency in French: Comparing Regular Classroom, Study Abroad, and Intensive Domestic Immersion Programs». Studies in Second Language Acquisition, 26(2): 275-301.

Freed, B. F., So, S. \& Lazar, N. (2003). Language Learning Abroad: How Do Gains in Written Fluency Compare with Gains in Oral Fluency in French as a Second Language? ADFL Bulletin, 34(3): 34-40.

Ginsberg, R., Robin, R. \& Wheeling, P. (1992). «Listening comprehension before and after study abroad». National Foreign Language Center Working Papers. Washington D.C.: National Foreign Language Center.

Guntermann, G. (1992a). "An analysis of interlanguage development over time: Part I, por and para». Hispania, 75: 177-187.

Guntermann, G. (1992b). «An analysis of interlanguage development over time: Part II, ser and estar». Hispania, 75: 1294-1303.

Ife, A. Vives Boix, G. \& Meara, P. (2000). «The impact of study abroad on the vocabulary development of different proficiency groups». Spanish Applied Linguistics, 4(1): 55-84.

Isabelli, C. A. \& Nishida, C. (2005). «Development of the Spanish Subjunctive in a Nine month Study-abroad Setting». In D. Eddington (ed.) Selected proceedings of the 6th conference on the Acquisition of Spanish and Portuguese as First and Second Languages (pp. 7891. Somerville, MA: Cascadilla Press.

Isabelli-García, C. A. (2003). «Development of oral communication skills abroad». Frontiers, IX: 149-173.

Isabelli-García, C. A. (2006). «Study abroad social networks, motivation and attitudes: implications for second language acquisition». In M. A. DuFon and E. Churchill (eds.), Language Learners in Study Abroad Contexts (pp. 231-258). Clevedon: Multilingual Matters.

Juan-Garau, M. \& Pérez-Vidal, (2007). «The effect of context and contact on oral communication in students who go on a stay abroad». EUROSLA Yearbook 2007. Amsterdam: Walter Benjamins. 
Kline, R. (1998). «Literacy and Language Learning in a Study Abroad Context». Frontiers, IV: $139-65$.

Lafford, B. A. (1995). "Getting into, through and out of a survival situation: A comparison of communicative strategies used by students studying Spanish abroad and 'at home'». In B. Freed (ed.), Second Language Acquisition in a Study Abroad Context (pp. 97-121 ). Amsterdam: John Benjamins.

Lafford, B. A. (2004). «The effect of the context of learning on the use of communication strategies by learners of Spanish as a second language». Studies in Second Language Acquisition 26(2): 201-225.

Lafford, B. A. (2006). «The effects of study abroad vs. classroom contexts on Spanish SLA: Old assumptions, new insights and future research directions». In C. A. Klee \& T. L. Face (eds.) Selected Proceedings of the 7th Conference on the Acquisition of Spanish and Portuguese as First and Second Languages. (pp. 26-39). Somerville, MA: Cascadilla Press.

Lafford, B. \& Ryan, J. (1992). «Acquisition of lexical meaning in a natural environment: «ser» and «estar» and the Granada experience». Hispania, 75(3): 714-722.

Lapkin, S., Hart, D. \& Swain, M. (1995). «A Canadian interprovincial exchange: evaluating the linguistic impact of a three-month stay in Quebec». In B. Freed (ed.), Second Language Acquisition in a Study Abroad Context (pp. 67-94) Amsterdam: John Benjamins.

Marriott, H. (1995). «The acquisition of politeness patterns by exchange students in Japan». In B. Freed (ed.), Second Language Acquisition in a Study Abroad Context (pp. 197-224) Amsterdam: John Benjamins.

Meara, P. (1994). «The year abroad and its effects». Language Learning, 10: 32-38.

Mendelson, V. G. (1998). «Hindsight is 20/20: Student Perceptions of Language Learning and the Study Abroad Experience». Frontiers, IV: 43-63.

Milton, I. \& Meara, P. (1995). «How periods abroad affect vocabulary growth in a foreign language». ITL Review of Applied Linguistics, 107-108: 17-34.

Mora, J. C. (2005). «Learning context effects on the perception of phonemic contrasts by bilingual Spanish/Catalan learners of English». Paper presented at the 23rd AESLA Applied Linguistics Congress, Palma de Mallorca, Spain.

Mora, J.C. (2006). «Learning context effects on the production of English stop consonants by bilingual Catalan/Spanish learners of English». Paper presented at the 24 $4^{\text {th }}$ AESLA Applied Linguistics Congress, Madrid, Spain.

Norris, J. M. \& Ortega, L. (eds.) (2006). Synthesizing research on language learning and teaching. Philadelphia: John Benjamins.

Pellegrino, V. A. (1998). «Student perspectives on language learning in a study abroad context». Frontiers, IV: 91-120.

Polanyi, L. (1995). «Language learning and living abroad: stories from the field». In B. F. Freed (ed.) Second Language Acquisition in a Study Abroad Context (pp. 271-291). Amsterdam: John Benjamins.

Rees, J. \& Klapper, J. (2008). «Issues in the quantitative longitudinal measurement of second language progress in the study abroad context». In L. Ortega \& H. Byrnes (eds.), The Longitudinal Study of Advanced L2 Capacities (pp. 89-105). NY: Routledge

Regan, V. (1995). "The acquisition of sociolinguistic native speech norms». In B. Freed (ed.), Second Language Acquisition in a Study Abroad Context (pp. 245-267) Amsterdam: John Benjamins.

Regan, V. (1998). «Sociolinguistics and language learning in a study abroad context». Frontiers, IV: 61-90. 
Rivers, W. P. (1998). «Is being there enough? The effects of homestay placements on language gain during study abroad». Foreign Language Annals, 31(4): 492-500.

Sasaki, M. (2004). «A multiple data analysis of the 3.5-year development of EFL student writers». Language Learning, 54(3): 525-582.

Sasaki, M. (2007) «Effects of Study-Abroad Experiences on EFL Writers: A Multiple-Data Analysis». The Modern Language Journal, 91(4): 602-620.

Sasaki, M. (2009). "Changes in EFL students' writing over 3.5 years: A socio-cognitive account». In R. Manchón (ed.) Learning, teaching and researching writing (pp. 49-76) Clevendon: Multilingual Matters.

Segalowitz, N., \& Freed, B. F. (2004). «Context, Contact and Cognition in Oral Fluency Acquisition: Learning Spanish in At Home and Study Abroad Contexts». Studies in Second Language Acquisition, 26(2): 173-199.

Tanaka, K. \& Ellis, R. (2003). «Study-abroad, language proficiency and learner beliefs about language learning». JALT Journal, 25(1): 63-85.

Teichler, U. \& Maiworm, F. (1997). «The ERASMUS experience: Major findings of the ERASMUS evaluation research project». Luxembourg: Office for Official Publications of the European Community.

Wilkinson, S. (1998). «Study abroad from the participants' perspective: A challenge to common beliefs». Foreign Language Annals, 31(1): 23-39.

Williams, T. (2005). «Exploring the Impact of Study Abroad on Students' Intercultural Communication Skills: Adaptability and Sensitivity». Journal of Studies in International Education, 9(4): 356-371.

Willis, F., Doble, G., Sankarayya, U. \& Smithers, A. (1977). Residence abroad and the student of modern languages. A preliminary study. Bradford: Modern Language Centre.

Yager, K. (1998). «Learning Spanish in Mexico: The effect of informal contact and student attitudes on language gain». Hispania, 81(4): 898-913 
Appendix 1. Summary of empirical research comparing SA and AH learning experiences.

\begin{tabular}{|c|c|c|c|c|c|c|c|c|c|}
\hline \multirow{3}{*}{ STUDY } & \multirow{3}{*}{ AREA } & \multicolumn{7}{|c|}{ METHOD } & \multirow{3}{*}{ RESULTS } \\
\hline & & \multicolumn{4}{|c|}{ Participants } & \multicolumn{3}{|r|}{ Design } & \\
\hline & & $\mathbf{N}$ & L1 & L2 & L2 Level & Duration & Approach & Instruments & \\
\hline $\begin{array}{l}\text { Collentine } \\
(2004)\end{array}$ & $\begin{array}{l}\text { Lexical \& } \\
\text { grammatical } \\
\text { development }\end{array}$ & $\begin{array}{l}\mathrm{AH}=20 \\
\mathrm{SA}=26\end{array}$ & English & Spanish & $3^{\text {rd }}$ semester & 16 weeks & Pre \& post tests & OPI & $\begin{array}{l}\text { SA }<\text { AH in lexical density \& } \\
\text { grammatical abilities } \\
\text { SA }>\text { AH narrative abilities }\end{array}$ \\
\hline DeKeyser (1990) & $\begin{array}{l}\text { Monitoring } \\
\text { grammar }\end{array}$ & $\begin{array}{l}\mathrm{AH}=5 \\
\mathrm{SA}=7\end{array}$ & English & Spanish & $\begin{array}{l}\text { Intermediate } \\
3^{\text {td }} \text { year }\end{array}$ & 16 weeks & $\begin{array}{l}\begin{array}{l}\text { Longitudinal } \\
\text { (beg/mid/post) }\end{array} \\
\text { (b) }\end{array}$ & $\begin{array}{l}\text { Grammar test / interview / picture } \\
\text { description / observation }\end{array}$ & $\begin{array}{l}\mathrm{SA}=\mathrm{AH} \text { in monitoring } \\
\text { grammar }\end{array}$ \\
\hline DeKeyser (1991) & $\begin{array}{l}\text { Oral comm. } \\
\text { strategies }\end{array}$ & $\begin{array}{l}\mathrm{AH}=5 \\
\mathrm{SA}=7\end{array}$ & English & Spanish & Intermediate & 16 weeks & $\begin{array}{l}\text { Longitudinal } \\
\text { (beg/mid/post) }\end{array}$ & $\begin{array}{l}\text { Grammar test / interview / picture } \\
\text { description/ recall / observation }\end{array}$ & $\mathrm{SA}=\mathrm{AH}$ in CSs use \\
\hline $\begin{array}{l}\text { Díaz-Campos } \\
\text { (2004) }\end{array}$ & Pronunciation & $\begin{array}{l}\mathrm{AH}=20 \\
\mathrm{SA}=26\end{array}$ & English & Spanish & $3^{\text {td }}$ semester & 10 weeks & Pre \& post tests & Read aloud task & $\mathrm{SA}=\mathrm{AH}$ in reading task \\
\hline $\begin{array}{l}\text { Díaz-Campos } \\
(2006)\end{array}$ & Pronunciation & $\begin{array}{l}\mathrm{AH}=20 \\
\mathrm{SA}=26\end{array}$ & English & Spanish & $\begin{array}{l}3^{\text {td }} \text { semester } \\
\text { Low-interm. }\end{array}$ & 16 weeks & Pre \& post tests & $\begin{array}{l}\text { Read aloud task } \\
\text { OPI }\end{array}$ & $\mathrm{SA}>\mathrm{AH}$ in conversational task \\
\hline Freed (1995) & Oral fluency & $\begin{array}{l}\mathrm{AH}=15 \\
\mathrm{SA}=15\end{array}$ & English & French & Varied & 16 weeks & Pre \& Post tests & OPI & $\mathrm{SA}>\mathrm{AH}$ oral fluency \\
\hline $\begin{array}{l}\text { Freed, } \\
\text { Segalowitz \& } \\
\text { Dewey (2004) }\end{array}$ & $\begin{array}{l}\text { Oral fluency \& } \\
\text { performance }\end{array}$ & $\begin{array}{l}\mathrm{AH}=8 \\
\mathrm{SA}=8 \\
\mathrm{IM}=12\end{array}$ & English & French & $3^{\text {rd }}-5^{\text {th }}$ year & $\begin{array}{l}\text { AH } 12 w \\
\text { SA } 12 \text { w } \\
\text { IM } 7 w\end{array}$ & Pre \& post tests & Similar to OPI & $\begin{array}{l}\mathrm{IM}>\mathrm{SA}>\mathrm{AH} \text { in oral fluency } \\
\& \text { performance }\end{array}$ \\
\hline $\begin{array}{l}\text { Freed, So \& } \\
\text { Lazar (2003) }\end{array}$ & Written fluency & $\begin{array}{l}\mathrm{AH}=4 \\
\mathrm{SA}=4\end{array}$ & English & French & Varied & 16 weeks & Pre \& post tests & $\begin{array}{l}\text { Analytic measures (fluency, complexity, } \\
\text { accuracy) } \\
\text { NSs' subjective ratings }\end{array}$ & $\begin{array}{l}\mathrm{SA}=\mathrm{AH} \text { NSs' ratings } \\
\mathrm{SA}>\mathrm{AH} \text { total no of words }\end{array}$ \\
\hline Huebner (1995) & $\begin{array}{l}\text { Linguistic } \\
\text { progress } \\
\text { (Several areas) } \\
\end{array}$ & $\begin{array}{l}\mathrm{AH}=12 \\
\mathrm{SA}=10\end{array}$ & $\begin{array}{l}\text { English/ } \\
\text { Asian } \\
\text { languages }\end{array}$ & Japanese & Beginners & 9 weeks & $\begin{array}{l}\text { Longitudinal } \\
\text { (beg/mid/post) }\end{array}$ & $\begin{array}{l}\text { Proficiency test/ OPI / Narrative retelling } \\
\text { /OSI / Observation / Diary entries / } \\
\text { Interviews }\end{array}$ & $\begin{array}{l}\mathrm{SA}>\mathrm{AH} \text { slightly higher } \mathrm{OPI} \\
\& \text { reading test } \\
\mathrm{SA}=\mathrm{AH} \text { learning strategies }\end{array}$ \\
\hline $\begin{array}{l}\text { Isabelli \& } \\
\text { Nishida (2005) }\end{array}$ & $\begin{array}{l}\text { Morpho-syntactic } \\
\text { pattern }\end{array}$ & $\begin{array}{l}\mathrm{AH}=32 \\
\mathrm{SA}=29\end{array}$ & English & Spanish & $\begin{array}{l}\text { AH Intermed. } \\
\text { SA Advanced }\end{array}$ & 36 weeks & $\begin{array}{l}\text { Longitudinal } \\
\text { (pre/mid/post) }\end{array}$ & SOPI & $\mathrm{SA}>\mathrm{AH}$ in subjunctive use \\
\hline Lafford (1995) & $\begin{array}{l}\text { Oral comm. } \\
\text { strategies }\end{array}$ & $\begin{array}{l}\mathrm{AH}=13 \\
\mathrm{SA} 1=13 \\
\mathrm{SA} 2=16\end{array}$ & English & Spanish & $\begin{array}{l}4^{\text {th }} \text { semester } \\
\text { (varied) }\end{array}$ & 16 weeks & Post test & OPI (only role play) & $\begin{array}{l}\mathrm{SA}>\mathrm{AH} \text { slightl. higher OPI } \\
\mathrm{SA}>\mathrm{AH} \text { broader CSs } \\
\text { repertoire }\end{array}$ \\
\hline Lafford (2004) & $\begin{array}{l}\text { Oral comm. } \\
\text { strategies }\end{array}$ & $\begin{array}{l}\mathrm{AH}=20 \\
\mathrm{SA}=26\end{array}$ & English & Spanish & $3^{\text {rd }}$ semester & 16 weeks & Pre \& post tests & OPI & $\mathrm{SA}>\mathrm{AH}$ less frequent $\mathrm{CSs}$ use \\
\hline Sasaki (2004) & Writing & $\begin{array}{l}\mathrm{AH}=5 \\
\mathrm{SA}=6\end{array}$ & Japanese & English & 6 years & $\begin{array}{l}8 / 32 \text { weeks } \\
\text { +long term }\end{array}$ & Longitudinal & $\begin{array}{l}\text { SLEP test / Composition scores / } \\
\text { retrospective accounts / interviews }\end{array}$ & $\begin{array}{l}\text { SA=AH written fluency } \\
\text { SA }>\text { AH writing styles \& } \\
\text { strategies \& motivation }\end{array}$ \\
\hline Sasaki (2007) & Writing & $\begin{array}{l}\mathrm{AH}=6 \\
\mathrm{SA}=7\end{array}$ & Japanese & English & $\begin{array}{l}\text { Low - mid } \\
\text { intermediate }\end{array}$ & $\begin{array}{l}8 / 36 \text { weeks } \\
\text { +long term }\end{array}$ & Longitudinal & $\begin{array}{l}\text { SLEP test / Composition scores / Recall } \\
\text { protocols / Interviews / Reports }\end{array}$ & $\begin{array}{l}\text { SA > AH in composition } \\
\text { scores, writing fluency \& self } \\
\text { confidence }\end{array}$ \\
\hline $\begin{array}{l}\text { Sasaki } \\
(2009)\end{array}$ & Writing & $\begin{array}{l}\mathrm{AH}=5 \\
\mathrm{SA}=17\end{array}$ & Japanese & English & 8 years & $\begin{array}{l}8 / 44 \text { weeks } \\
\text { +long term }\end{array}$ & Longitudinal & $\begin{array}{l}\text { Composition scores } \\
\text { Interviews }\end{array}$ & $\begin{array}{l}\begin{array}{l}\mathrm{SA}>\mathrm{AH} \text { in composition } \\
\text { scores \& intrinsic motivation }\end{array} \\
\end{array}$ \\
\hline $\begin{array}{l}\text { Segalowitz \& } \\
\text { Freed (2004) }\end{array}$ & $\begin{array}{l}\text { Oral proficiency } \\
\text { performance \& } \\
\text { fluency }\end{array}$ & $\begin{array}{l}\mathrm{AH}=18 \\
\mathrm{SA}=22\end{array}$ & English & Spanish & $3^{\text {rd }}$ semester & 16 weeks & Pre \& post tests & $\begin{array}{l}\mathrm{OPI} / \text { journals / lexical access attention } \\
\text { control / interviews }\end{array}$ & $\begin{array}{l}\mathrm{SA}>\mathrm{AH} \text { in oral fluency and } \\
\text { proficiency }\end{array}$ \\
\hline
\end{tabular}

